\title{
Process Standardization and Quality Evaluation of Buttermilk and Lemon RTS by adding Red Yeast Rice Powder as Food Colorant
}

\author{
D. D. Toshniwal ${ }^{1 *}$, H. W. Deshpande ${ }^{1}$, S.D. Katke ${ }^{1}$ and N.M. Tamboli ${ }^{2}$ \\ ${ }^{1}$ Dept. of Food Microbiology \& Safety, ${ }^{2}$ Dept. of Agricultural Engineering, College of \\ Agriculture, VNMKV, Latur, Maharashtra, India \\ *Corresponding author
}

\section{A B S T R A C T}

\section{Keywords}

Bio colorant,

Monascus

purpureus, Red

yeast rice, Lemon

juice, Buttermilk,

RTS, Red yeast rice

powder, RYRP

Article Info

Accepted:

18 August 2020

Available Online:

10 September 2020
The present study was carried out to justify acceptability of Red Yeast Rice Powder (RYRP) as a colorant. Addition of 1.0 percent Red Yeast Rice powder to lemon juice and buttermilk was scored highest in terms of color, texture and appearance parameters. The prepared Red yeast Rice powder was stable at room temperature for 90 days when properly packed in suitable packaging material. On the basis of findings, it was concluded that the products prepared by using Red Yeast Rice powder as a colorant could be considered as the best from both nutritional and sensory point of view. It is also economically feasible than synthetic colorants which are being sold in market.

\section{Introduction}

India ranks second as a producer and consumer of rice in the world and it contributes for about $22.3 \%$ of global production. Red yeast rice (RYR) could be a nutraceutical made by fermentation of polished rice with the mold Monascus purpureus and other related species of molds. Red Yeast Rice (RYR) contains various compounds like polyketides, pigments, monacolins, unsaturated fatty acids, and phytosterols. Red Yeast Rice (RYR) has been used as an herbal supplement and in the cooking of East Asian countries like China, Japan, and Korea. Red Yeast Rice has been utilized as an herbal additive and in the cooking of food East Asian countries like China, Japan, and Korea. It has been used for flavoring, coloring, and preservation of food and in traditional Chinese medicine for many years (Burke et. al., 2015).

Red Yeast Rice is the fermented product which is produced from normal rice (Oryza sativa) with red mold (Monascus spp.). Red 
yeast rice is also known with various another name which are ang-kak, hung-chu, hon-chi, hong-gug in Korean, red koji, benikoji, and so on. It has an extended historyas a flavoring, coloring and preservative in food and a folk medicine in many Asian countries. The RYR product is noted to by different names as per the local languages (Woranan and Prasad 2015,). Many species of the mold Monascus have also been widely used in making different products like red wine and red soybean cheese (Chen et. al., 1987). (Hesseltine et. al., 1979) The mold Monascus first became known in Western world when van Tieghem (1884) enlisted the use of red powder (red yeast rice) by local populations in Java islands. The fungus that was separated from red mold rice was named Monascus purpureus Went by scientist (Went, 1895), in recognition of the purple color. Today there are more than 30 Monascus strains which are deposited with the American Type Culture Collection (ATCC) or other Institutes like Microbial Type Culture Collection (MTCC), India. Products fermented by Monascus (MFPs) are produced by fermentation process with Monascus species through solid state fermentation or submerged fermentation processes. The common species of Monascus which are usually used for the fermentation are Monascus purpureus, Monascus pilosus, Monascus anka and Monascus ruber. The usual Monascus yielded products which were consumed over the centuries in Asian countries are Red Mold Rice (RMR), is termed as angkak, anka, and red yeast rice. It has been used from earlier period as food colorant and food preservative, food supplement and in traditional medicine. Scientific studies have confirmed pharmacological effects of Monascus fermentate (Endo et. al., 1989) isolated from Monascus purpureus a metabolite, monacolin $\mathrm{K}$, which normalized an artificially induced hyperlipoproteinemia in human trials. The reduced form Mevinolin has been introduced as a cholesterol reducing pharmaceutical. Simple extracts of fermentate lower the HDL cholesterol and triglycerides value in blood (Fink et. al., 1989).

Rice (Oryza sativa L.) is important food for over more than Thirty percent of India's population, thus holds the key role in food security and plays a very important role in financial setup of national economy. The demand for rice is predicted to grow continuously as population is continuously growing. The rice plant belongs to the monocot genus Oryza of Poaceae family. The monocot genus Oryza includes 24 species, of which only two species are widely cultivated like, Oryza sativa and Oryza glaberrima, are cultivable and the rest 22 species are wild. Rice varieties i.e. sativa is further divided into three subspecies that are, japonica, indica, and javanica. India is that producer of rice varieties which belongs to the subspecies indica Department of Rural Development (DRD 2014). Rice is an annual plant which usually grows to a height of about $0.5-2 \mathrm{~m}$ (Gulshan Mahajan et al., 2017).

Red Yeast Rice Powder (RYR) can be used as a colorant to formulate different food products like Ice-cream, Colored sweetened milk, colored lemon juice, colored buttermilk, etc. which improves appearance whereas, Monacolins and $\mathrm{HmG}$ co-A reductase have shown reduced risk of cardiovascular diseases and promotes health benefits of Red yeast rice. Thus, it is clear that RYR could be successfully value added. Hence, it can be concluded that the RYR is a potential food supplement prepared from solid state rice fermentation which could be in addition to daily diet. Red Yeast Rice (RYR) can be implemented on commercial scale. RYR contains many compounds including polyketides, MUFA's, phytosterols, pigments, and monacolins (Patel et. al., 2016). Monacolins prohibit activity of enzyme (3- 
hydroxy-3-methylglutaryl- coenzyme A) HMG CoA reductase, which limits cholesterol synthesis. There are at the minimum 13 different monacolin compounds have been isolated from RYR, of which some like monacolin $\mathrm{K}$ is chemically similar to lovastatin, which is a cholesterol-lowering drug (Zhang, et al., 2016). Ma, 2000 announced that a red mold rice product traditionally manufactured with Monascus purpureus had a pigment content of $0.3 \%$ in rice flour. Hajjaj, et al., 1999 stated that New food applications, like the coloration of processed meats and other meat products (sausage, ham), marine products like fish paste, surimi, tomato ketchup, yoghurt, wine production, flavored milk, and fruit juices or other fruit products were described.

\section{Materials and Method}

\section{Procurement of raw ingredients}

Different raw materials that are needed for the preparation of Red yeast rice such as Rice, salt, etc. were purchased from the local market. The culture of Monascus purpureus was procured from Microbial Type Culture Collection, Chandigarh (MTCC).

\section{Standardization of procedure for preparation of red yeast rice}

Red Yeast Rice is produced by Solid state fermentation of white non sticky rice with Monascus purpureus. The Monascus purpureus culture is obtained from Microbial Type Culture Collection, Chandigarh (MTCC). To get culture in the vegetative phase the spores were streaked or poured onto sterilized petriplates of PDA (Potato Dextrose Agar). Which were then kept for incubation at $28^{\circ} \mathrm{C}$ for 5 to 7 days. The Standard culture is obtained from above Mother culture which was then stored under aseptic conditions and Working culture was used for further investigation and studies in the research.

\section{Revival of Monascus purpureus Spores}

Mother Culture<smiles></smiles>

Preparation of Potato Dextrose Agar<smiles></smiles>

Sterilization of PD Agar in autoclave at $121^{\circ} \mathrm{C}$ for 30 minutes<smiles>[Tl]</smiles>

Transfer of PD Agar into pre-sterilized petri plates<smiles></smiles>

Allow agar to solidify in petri plates

Transfer a loopful of culture from mother culture tube into solidified cooled petri plates<smiles></smiles>

Keep inoculated petri plates in incubator for 5 to 7 days at $28^{\circ} \mathrm{C}$<smiles>[CH]=C</smiles>

Observe for the red colored cottony growth of Monascus purpureus

\section{Flowsheet 1: Revival of Monascus} purpureus spores

\section{Solid state fermentation}

Rice variety, that is white and non-sticky after cooking was used in this study. The SSF was performed by following the method explained by scientist (Chairote et al., 2007) with some changes. Rice was soaked in water overnight, after that $50 \mathrm{~g}$ of rice were placed in a 250 mlErlenmeyer flask and autoclaved at $121^{\circ} \mathrm{C}$ for 15 minutes. The moisture content of each rice variety was adjusted to $60 \%(\mathrm{w} / \mathrm{w})$ on a wet basis. After cooling, $2.5 \%$ of the liquid fungal inoculum was added and the inoculated flasks were incubated at $30^{\circ} \mathrm{C}$ in the darkness. After 14days, the fermented rice was collected and observed for color pigment development and this pigmented rice was dried at $60^{\circ} \mathrm{C}$ for 4 to 6 hours. In this study three replications were made for rice variety. 


\section{Procedure for preparation of red yeast rice}

Stepwise production of Red Yeast Rice is carried out by firstly immersion of rice in water for 6 hours following by steaming for $20 \mathrm{~min}$. After that the cooked rice was cooled, from that accurately, $50 \mathrm{~g}$ of steam rice was transferred in $250 \mathrm{ml}$ cotton Stoppered Erlenmeyer flask and sterilized at $15 \mathrm{psi}$ pressure and $121^{\circ} \mathrm{C}$ temperature for $15 \mathrm{~min}$. One week old pure and precultured Monascus purpureus was used as inoculums at 2.5\% weight basis. The inoculated rice was incubated at $30^{\circ} \mathrm{C}$ for $14-16$ days with constant observations to check the pure growth conditions. The end-product was dried in the oven at temperature not exceeding $65^{\circ} \mathrm{C}$ for 4 to 6hours to obtain dried red yeast rice. The dried RYR is then powdered using domestic blender (Table 1).

Take $100 \mathrm{gm}$ of rice in $1000 \mathrm{ml}$ conical flask \]

Wash 3 to 4 times with ample quantity of water<smiles>[Te]</smiles>

Prepare $200 \mathrm{ml}$ of 0.86 percent saline solution (For this dissolve $0.086 \mathrm{gm} \mathrm{NaCl}$ in $10 \mathrm{ml}$ of water and adjust $\mathrm{pH} 6.7$ with $\mathrm{HCl}$ )<smiles>[Te]</smiles>

Transfer the solution into conical flask and shake thoroughly<smiles>[Te]</smiles>

Place a cotton topper on the neck of conical flask<smiles>[Li]</smiles>

Sterilize it in autoclave at $121^{\circ} \mathrm{C}$ for 25 minutes

(Let the flask cool till it reaches the normal temperature)<smiles>[Li]</smiles>

Check Rice grains if they are completely cooked

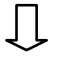

To this cooked rice add Monascus purpureus culture at 2 percent<smiles>[Te]</smiles>

Incubate in Incubator at $28^{\circ} \mathrm{C}$ for $10-14$ days<smiles>[CH]</smiles>

Check for color pigment production intermittently

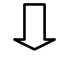

Transfer the fermented rice from conical flask to the clean and sterilized petri plate and spread evenly<smiles>[Li]</smiles>

Dry it in oven at $55^{\circ} \mathrm{C}$ for 5-6 hours or until moisture content is reduced $10 \%$<smiles>[Te]</smiles>

Grinding into powder with uniform particle size and packing in Aluminum foil with

LDPE<smiles>[Te]</smiles>

Store it in cool and dry place.

\section{Exploration of RYR in Buttermilk}

Boil milk and let it cool to warm temperature<smiles>[Te]</smiles>

Add Dahi or yoghurt starter, stir it and keep it undisturbed for overnight<smiles>[Te]</smiles>

Whisk Dahi with hand blender for 2 minutes<smiles>[Te]</smiles>

Add chilled water and let butter separate out

Add ice cubes till butter firms up<smiles>[Te]</smiles>

Remove butter and strain remaining liquid<smiles>[Li]</smiles>

Add powdered RYR at given concentrations and mix well

\&

Buttermilk is ready to be served

Flow Sheet 3: Preparation of Buttermilk (Table 2) 


\section{Exploration of RYR in Lemon RTS}

Take lemon and squeeze out about $10 \mathrm{ml}$ juice with squeezer.

Add colored chilled water, sugar and salt to lemon juice.<smiles>[Li]</smiles>

Mix well till all of the sugar and salt is dissolved.

Add 2 to 3 ice cubes and serve chilled.

\section{Flowsheet 4: Preparation of Lemon RTS} (Table 3)

\section{Results and Discussion}

\section{Physico-chemical properties of selected rice variety}

The physical characteristics of Rice play a very important role in development of processing technology. Data from Table 4 showed that the weight of 1000 grains were $18.66 \mathrm{gm}$, whereas length, width, thickness of flaxseed was $5.41 \mathrm{~mm}, 2.61 \mathrm{~mm}$, and $1.83 \mathrm{~mm}$ respectively. The shape and color were observed visually, the shape of Rice was found to be slender and color was white.

\section{Chemical composition of rice}

From Table 5 it can be seen that the moisture content in Rice was 9.2 percent and carbohydrate content was high and found to be 74.8 percent. The fat content was low at 0.9 percent and protein content was moderate in concentration i.e. 8.4 percent. Ash content of Rice was found to be 0.84 percent.

\section{Effect of cooking on chemical composition of rice}

From Table 6 we can see that the nutritional composition of raw and cooked rice varies greatly and found out as Moisture content of cooked rice as increased to 64.04 percent, whereas carbohydrates, fat, and proteins are decreased to 27.8 percent, 0.45 percent, and 2.76 percent respectively. The ash content of cooked rice is negligible at 0.3 percent.

\section{Mineral composition of rice}

The concentration of these minerals was recorded to be $80.54,350.40$, and 140.65 $(\mathrm{mg} / 1000 \mathrm{~g})$ respectively. The concentration of Calcium, Phosphorus, and Magnesium were much higher than the other inorganic minerals (Table 7).

\section{Exploration of red yeast rice powder as a colorant in buttermilk}

The RYR powder concentration in samples is kept at blank for $\mathrm{T}_{0}$ sample, for $\mathrm{T}_{1}$ the powder is added at 1.5 percent, for $\mathrm{T}_{2}$ it was 1.0 percent and for $\mathrm{T}_{3}$ it was kept at 0.5 percent. The color added was stable for upto15 days in refrigerated conditions with no visual fading or discoloration. Data given in Table 8 revealed that the overall acceptability score recorded for sample T2 was found higher (8.00) followed by T0 (7.38) than other samples. The acceptance of samples depends on the ingredient variation. The overall acceptability among samples was significantly varied statistically. The color and appearance serve as important parameters for the acceptance of food samples.

The highest score for color of complementary juice was recorded for sample T2 (8.0). Whereas, the lowest score received for control sample T0 (7.0). There was a significant difference between the samples in context to color. The maximum score for flavor attribute was received by sample T2 (7.5). While, least score was noted for sample T2 (6.5). The taste of Lemon juice in Table 8 showed that the formulation $\mathrm{T} 2$ got the highest value for taste (8.00) and lowest T1 (7.0). 
Exploration of red yeast rice powder as a colorant in lemon RTS

The RYR powder concentration in samples is kept at blank for $\mathrm{T}_{0}$ sample, for $\mathrm{T}_{1}$ the powder is added at 1.5 percent, for $\mathrm{T}_{2}$ it was 1.0 percent and for $\mathrm{T}_{3}$ it was kept at 0.5 percent. Information given in Table 9 explains that the overall acceptability score for sample T2 was found higher (8.25) followed by T3 (7.50) than other samples. The acceptance of samples depends on the ingredient variation. The overall acceptability among samples was significantly varied statistically. The color and appearance serve as important parameters for the acceptance of food samples. The highest score for color of complementary juice was recorded for sample T2 (8.6). Whereas, lowest score was received for control sample T0 (7.0). There was a significant difference between the samples in context to color. The maximum score for flavor attribute was received by sample $\mathrm{T} 2$ (7.8). While least score was noted in case of sample T3 (6.5). The taste of Lemon juice in table7 showed that the formulation $\mathrm{T} 2$ got the highest value for taste (8.6) against T1 (7.0). There was a significant difference among the samples in context to all the sensory parameters. Overall, by considering the different sensory attributes, the formulation
T2 was found to be superior to the other samples (Fig. 1 and 2).

\section{Nutritional content of buttermilk added with RYR powder}

Buttermilk is a traditional fermented dairy product (drink). Traditionally it was the clear liquid left after churning butter out of cream. It is a cultured product; however, it is common in warm climates where unrefrigerated milk sours quickly. The product is chosen to give it red color instead of its long known white color which will increase its appearance. The proximate chemical composition of Buttermilk is given in Table 10.

\section{Nutritional content of lemon RTS added with RYR powder}

Lemon RTS is consumed by most of the people during the summer season because it provides instant energy and helps in maintaining body fluids. Color plays an important role in acceptability of Lemon RTS. Therefore, it was added with RYR powder which will give red color and thereby induce acceptability. A Typical nutrient composition Lemon RTS is given below in Table 11.

Table.1 Standardized recipe for preparation of red yeast rice powder

\begin{tabular}{|c|c|}
\hline Material & Quantity \\
\hline Rice & $100 \mathrm{gm}$ \\
Salt & $0.86 \mathrm{gm}$ \\
Water & $200 \mathrm{ml}$ \\
\hline
\end{tabular}

Table.2 Recipe for preparation of buttermilk

\begin{tabular}{|c|c|}
\hline Ingredients Required & Quantity \\
\hline Whole Milk & $500 \mathrm{ml}$ \\
Dahi or Yogurt starter & $10 \mathrm{ml}$ \\
Chilled water & $500 \mathrm{ml}$ \\
\hline
\end{tabular}


Table.3 Recipe for lemon RTS preparation

\begin{tabular}{|c|c|}
\hline Ingredients Required & Quantity \\
\hline Fresh Lemon Juice & $10 \mathrm{ml}$ \\
Sugar & $15 \mathrm{gm}$ \\
Salt & $0.5 \mathrm{gm}$ \\
Chilled Water & $100 \mathrm{ml}$ \\
\hline
\end{tabular}

Table.4 Physical properties of rice

\begin{tabular}{|c|c|}
\hline Physical Parameters & Observation \\
\hline Colour & White \\
Shape & Slender \\
Length (mm) & 5.41 \\
Width (mm) & 2.61 \\
Thickness (mm) & 1.83 \\
Wt. of 1000 seeds (g) & 18.36 \\
Angle of Repose (Degree) & 37.1 \\
Density (g/ml) & 1.42 \\
\hline
\end{tabular}

Table.5 Chemical properties of rice

\begin{tabular}{|c|c|}
\hline Chemical Parameters & Observation (\%) \\
\hline Moisture (\%) & 9.2 \\
Crude Fat (\%) & 0.9 \\
Total Carbohydrates (\%) & 74.8 \\
Total Protein (\%) & 8.4 \\
Ash (\%) & 0.84 \\
\hline
\end{tabular}

Table.6 Chemical composition of rice after cooking

\begin{tabular}{|c|c|}
\hline Chemical Parameters & Observation (\%) \\
\hline Moisture (\%) & 64.04 \\
Crude Fat (\%) & 0.45 \\
Total Carbohydrates (\%) & 27.8 \\
Total Protein (\%) & 2.76 \\
Ash (\%) & 0.3 \\
\hline
\end{tabular}

Table.7 Mineral content in rice

\begin{tabular}{|c|c|}
\hline Minerals & $\begin{array}{c}\text { Average value } \\
\text { (mg/1000g) }\end{array}$ \\
\hline Calcium & 80.54 \\
Phosphorus & 350.40 \\
Magnesium & 140.65 \\
\hline
\end{tabular}


Table.8 Sensory evaluation of buttermilk

\begin{tabular}{|c|c|c|c|c|c|}
\hline \multirow{2}{*}{ Treatments } & \multicolumn{4}{|c|}{ Sensory Characteristics } & \multirow{2}{*}{} \\
\cline { 2 - 5 } & $\begin{array}{c}\text { Colour \& } \\
\text { Appearance }\end{array}$ & Flavor & Texture & Taste & $\begin{array}{c}\text { Overall } \\
\text { Acceptability }\end{array}$ \\
\hline $\mathbf{T}_{\mathbf{0}}$ & 7.00 & 7.00 & 7.50 & 8.00 & 7.38 \\
\hline $\mathbf{T}_{\mathbf{1}}$ & 7.50 & 6.50 & 7.00 & 7.00 & 7.00 \\
\hline $\mathbf{T}_{\mathbf{2}}$ & $\mathbf{8 . 0 0}$ & $\mathbf{7 . 5 0}$ & $\mathbf{8 . 0 0}$ & $\mathbf{8 . 5 0}$ & $\mathbf{8 . 0 0}$ \\
\hline $\mathbf{T}_{\mathbf{3}}$ & 7.50 & 6.50 & 7.40 & 7.60 & 7.25 \\
\hline C.D. & 0.172 & 0.196 & 0.196 & 0.196 & 0.144 \\
\hline SE & 0.058 & 0.066 & 0.066 & 0.066 & 0.048 \\
\hline
\end{tabular}

Table.9 Sensory evaluation of colored lemon RTS

\begin{tabular}{|c|c|c|c|c|c|}
\hline \multirow{2}{*}{ Treatments } & \multicolumn{3}{|c|}{ Sensory Characteristics } & \\
\cline { 2 - 5 } & $\begin{array}{c}\text { Colour \& } \\
\text { Appearance }\end{array}$ & Flavor & Texture & Taste & $\begin{array}{c}\text { Overall } \\
\text { Acceptability }\end{array}$ \\
\hline $\mathbf{T}_{\mathbf{0}}$ & 7.000 & 7.500 & 7.500 & 7.500 & 7.380 \\
\hline $\mathbf{T}_{\mathbf{1}}$ & 7.500 & 6.500 & 7.000 & 7.000 & 7.000 \\
\hline $\mathbf{T}_{\mathbf{2}}$ & $\mathbf{8 . 6 0 0}$ & $\mathbf{7 . 8 0 0}$ & $\mathbf{8 . 0 0 0}$ & $\mathbf{8 . 6 0 0}$ & $\mathbf{8 . 2 5 0}$ \\
\hline $\mathbf{T}_{\mathbf{3}}$ & 7.500 & 6.500 & 7.500 & 7.500 & 7.500 \\
\hline C.D. & 0.196 & 0.196 & 0.156 & 0.196 & 0.172 \\
\hline SE & 0.066 & 0.066 & 0.052 & 0.066 & 0.058 \\
\hline
\end{tabular}

Table.10 Buttermilk added with RYR powder

\begin{tabular}{|c|c|}
\hline Nutrient & Quantity $($ per $\mathbf{1 0 0} \mathbf{~ m l})$ \\
\hline Energy & $29.3 \mathrm{kcal}$ \\
\hline Carbohydrates & $2.3 \mathrm{gm}$ \\
\hline Proteins & $1.7 \mathrm{gm}$ \\
\hline Fat & $1.5 \mathrm{gm}$ \\
\hline
\end{tabular}

Table.11 Lemon RTS added with RYR powder

\begin{tabular}{|c|c|}
\hline Nutrient & Quantity $($ per $\mathbf{1 0 0} \mathbf{~ m l})$ \\
\hline Energy & $48 \mathrm{kcal}$ \\
\hline Carbohydrates & $12.00 \mathrm{gm}$ \\
\hline Proteins & $1.00 \mathrm{gm}$ \\
\hline Fat & $0.00 \mathrm{gm}$ \\
\hline Vitamin C & $53 \mathrm{mg}$ \\
\hline
\end{tabular}


Table.12 Microbial analysis of red yeast rice powder

\begin{tabular}{|c|c|}
\hline Parameter & Observation \\
\hline Total Plate Count $(\mathrm{CFU} / \mathrm{mL})$ & ND \\
\hline Yeast and Mold Count $(\mathrm{CFU} / \mathrm{mL})$ & $\mathbf{6 . 4 \times 1 0 ^ { 8 }}$ \\
\hline Coliform Count $(\mathrm{MPN} / \mathrm{mL})$ & ND \\
\hline
\end{tabular}

Fig.1 Sensory evaluation of buttermilk

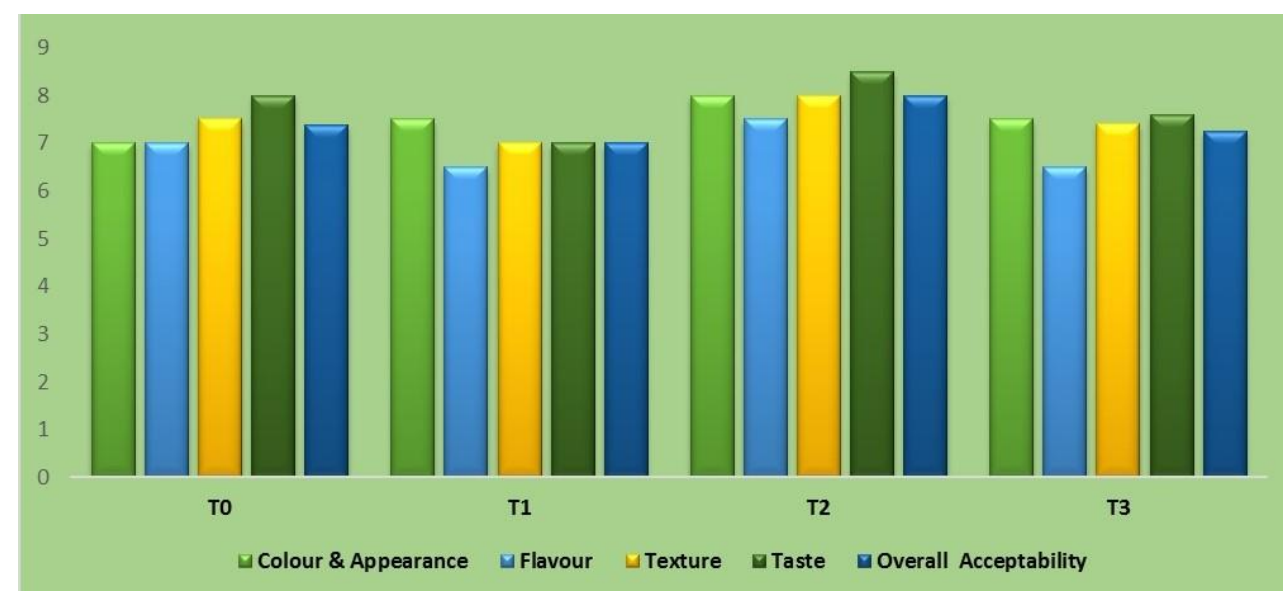

Fig.2 Sensory evaluation of lemon RTS

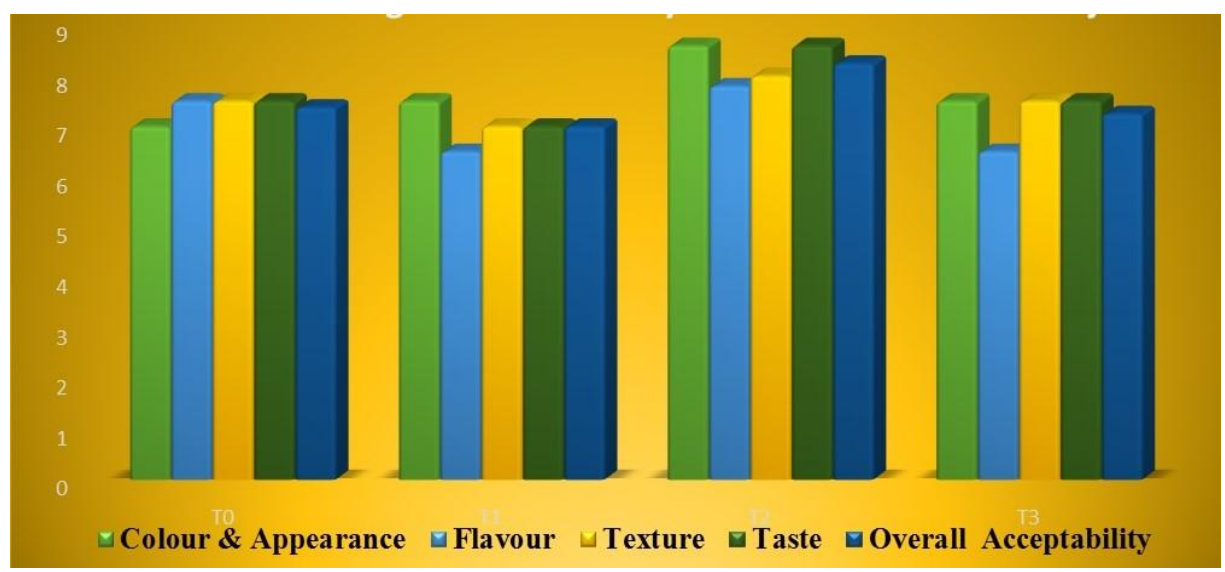

\section{Microbial analysis of red yeast rice powder}

The growth of harmful and unwanted microorganisms will spoil the prepared product and may lead to different types of food borne diseases which can affect the human health and body. Therefore, microbial analysis of the prepared powder is mandatory to prevent the product from spoilage and also maintain the safety. The data related to microbiological analysis of RYR powder is given in Table 12 .

In the present work, the count of beneficial mold was detected as $6.4 \times 10^{8} \mathrm{CFU} / \mathrm{ml}$ and bacterial count was not detected in a powder. This count was in suitable range as observed in similar food products. On the other hand, coliform measure was also carried out. Coliform were not detected in the prepared food sample, which showed that the prepared probiotic 
beverage was free of any pathogenic and harmful microbes and safe for consumption.

On the basis of findings, it was concluded that the products prepared by using Red Yeast Rice powder as a colorant could be considered as the best from both nutritional and sensory point of view. The Red Yeast Rice powder at the ratio of 1.0 percent was good in terms of color, texture and appearance. The prepared Red yeast Rice powder was stable at room temperature for 90 days when properly packed in suitable packaging material. The fact that it is cheap than the ones which are being sold in market. Hence, it can be concluded that Red Yeast Rice powder is economically feasible to explore on a commercial scale.

\section{References}

Burke, F.M. (2015): "Red yeast rice for the treatment of dyslipidemia". Current Atherosclerosis Report; 17(4): 495-498.

Chen X. P., (1987): "Research status on prescriptions for 52 diseases". J. Traditional Medicines; 5(1), 61-63.

DeFelice, S.L. (1995): “The nutraceutical revolution: its impact on food industry R\&D”. Trends in Food Science and Technology; 6 (1), 59-61.

Endo A., and Monacolin K. (1989): "A new hypocholestolemic agent that specifically inhibits 3-hydroxy-3-methulglutaryl coenzyme A reductase". Journal of Antibiotics; 33(3):334-4

Fink-Grammels J., and Leistner L. (2008): "Biochemical working on Monascus Purpureus". Food Microbiology; 126(2): 20-23.
Gulshan Mahajan, Vivek Kumar, and Bhagirath S. Chauhan (2017) Chapter 3, "Rice Production in India"; 54-88.

Hajjaj H., Klaebe A., Goma G., Blanc P. J., Barbier E., Francois J., (2000): "Medium- chain fatty acids affect citrinin production in the filamentous fungus Monascus ruber". Applied Environmental Microbiology; 66(3): 1105- 20.

Hesseltine C. W. (1979): "Solid-state fermentations an overview". International. Biodeteriorator; 23(1): 7989.

Ma, J. (2000): "Constituents of red yeast rice, a traditional Chinese food and medicine". Journal on Agricultural Food Chemistry; 48(1), 5220-5225.

Patel, S. (2016): "Functional food red yeast rice (RYR) for metabolic syndrome amelioration: a review on pros and cons". World Journal Microbiology and Biotechnology; 32(1), 2035-2042.

Tieghem V., (1884): "Monascus, genre nouveau de l'ordre des Ascomycetes". Bulletin de la Societe Botanique de France; 31(1): 226-231.

Went F. A. and F. C., (1895): "Monascus purpureus. le champignon de l'angquac une nouvelle the lebolee". Annales des Sciences Naturalles Botanics. Biodiversity; 8(1), 1-17.

Woranan N.and Prasad M.(2015): “ Increasing the Value of Rice by Transformation into Red Yeast Rice". Journal of Science and Technology; 34(5): 504-512.

Zhang Z., Ali Z., Khan S.I., and Khan I.A., (2016): "Cytotoxic monacolins from red yeast rice, a Chinese medicine and food". Food Chemistry. 202, 262-268.

\section{How to cite this article:}

Toshniwal, D.D., H.W. Deshpande, S.D. Katke and Tamboli, N.M. 2020. Process Standardization and Quality Evaluation of Buttermilk and Lemon RTS by adding Red Yeast Rice Powder as Food Colorant. Int.J.Curr.Microbiol.App.Sci. 9(09): 2583-2592. doi: https://doi.org/10.20546/ijcmas.2020.909.323 